\title{
Customer perception towards general insurance: A factor analysis approach
}

\author{
Ritu Gangil ${ }^{*}$, Swati Vishnoi ${ }^{2}$ \\ ${ }^{1,2}$ Assistant Professor, Dept. of Management, ${ }^{1}$ Guru Shree Shanthivijai Jain College for Women, Chennai, Tamil Nadu, ${ }^{2}$ Aditya College, \\ Gwalior, Madhya Pradesh, India
}

*Corresponding Author: Ritu Gangil

Email: gangil.ritu@gmail.com

\begin{abstract}
With the increase in risk there is need of insurance to bear the losses. Insurance is the instrument used as the financial protection against various contingency. This paper examines the customer perception towards the General Insurance. A study had been conducted at Gwalior region with the sample of 200 respondents to find out the perception of the customer (policyholders). In this context, the respondents' opinion on the various related statements were collected with a 5 point scaling. Reliability, Factor analysis, multivariate technique had been applied on the data. The result concluded that loyalty, transparency, proficiency, reliable and convenient services are the five factors from the 18 statements on the basis of the expectation of the customers. This study signifies that various customer had different expectation from the insurance company in the studied area.
\end{abstract}

Keywords: Insurance market, General insurance, Customer perception.

\section{Introduction}

In today's era everyone wants safety and protection. Insurance is an umbrella to protect from risk. Insurance is defined as sharing of the losses of unfortunate among those who are exposed to the same level of risks, suffering and destruction of damage to their properties which are likely to be caused by perils like accident, fire, theft and etc. Insurance is the type of investment which gives the financial security against any uncertainties. Insurance industry is growing industry which started from LIC life insurer and GIC non life insurer companies and due to rise in demand the private sector was allowed into insurance business. Foreign companies can serve in Indian market by joint venture with any Indian companies. However, foreign ownership was restricted not to exceed 26 per cent of foreign investment. The insurance industry in India is regulated by The Insurance Regulatory Development Act (IRDA), which has the object of ensuring effective administration, supervision, regulation and control the business of insurance in India. The insurance industry of India consists of 57 insurance companies of which 24 are in life insurance business and 33 are non-life insurers. Life Insurance Corporation (LIC) is the sole public sector company among the life insurer. There are six public sector insurers among non-life insurers in India. General Insurance Corporation of India (GIC Re) is the sole re- insurer in India. Brokers, surveyors and third party administrators servicing health insurance claims and agents (individual and corporate) are the other stakeholders in the Indian Insurance market.
Insurance provides various benefits to individuals, families, organizations and the country as whole. The insurance sector in India has become an open competitive market where there are many insurance companies serving different types of insurance products and services. By time insurance has gain much importance and now people prefer non life insurance to protect against risk. The development in the insurance sector in India reveals the 360 degree witnessed over a period of almost three centuries. The market size of gross non life insurers reached Rs. 962.05 billion for FY October 2019 with a growth rate of $12.40 \%$ as compare to FY October 2018. The premium figure signals that people want to ensure themselves in every aspect. With continuously increase in market share insurance sector is now full of open competition.

\section{Review of Literature}

Sharma $(2011)^{1}$ developed the managerial competency framework for the middle level managers of the general insurance sector in India. For the study survey was conducted among the 98 middle level managers of both private and public general insurance companies. The findings revealed communication skills, creativity, analytical skills, ability to delegate, flexibility, initiative, interpersonal skills, managerial skills, ability to motivate, ability to plan, job knowledge, team management, managerial skills and decision making were the 14 important competencies. Managerial skills and job knowledge were the most important skills.

Taha et al (2011) $)^{2}$ explained that loss reserve is one of the key factors that had influence many strategic decisions 
such as underwriting decisions, investment decisions, rate making decisions and corporate planning. Exponential smoothing model, Box-Jenkins analysis and time series regression model are applied on actual reported loss reserves data for general insurance sector for the period 1986 to 2006 and concluded that Exponential smoothing technique is the best forecasting technique to Egyptian general insurance sector.

Sandhu \& Bala $(2011)^{3}$ analyzed customers' perception towards life insurance. Data was collected through questionnaire consist of 34 statements from 337 customers of the three cities of Punjab. The result concluded seven factors i.e. proficiency, media \& presentations, physical \& ethical excellence, service delivery process \& purpose, security \& dynamic operations, credibility and functionality. They also investigated the relationship between each identified factors and customer evaluation for service quality. The findings revealed that Proficiency, Physical \& ethical excellence and Functionality were the significant factors which make impact on the overall service quality of Life Insurance.

Kavitha et al (2012) $)^{4}$ studied customer attitude towards general insurance. The study was done to know the customer attitude of erode district. For the study questionnaire of 25 statement on likert scale were designed and collected from the 750 respondents of the erode district. Factor analysis, multivariate techniques was applied on the data collected and group all statement into six factors i.e. loyalty conscious customers, trustworthy conscious respondents, agent conscious respondents, performance of the policy conscious respondents, policy transparency conscious respondents and bonus conscious respondents.

Turquet P. (2012) ${ }^{5}$ found that the Dutch, German and French health insurance systems had been attempting to contain cost and diversify the sources of finance which mainly come from social contributions.

Jain \& Lodha $(2012)^{6}$ analyzed the factors influence the customer satisfaction in general insurance. Questionnaire was used to collect data and data as collected from 200 general insurance policy holders of state of Rajasthan Thangadurai \& Rahim $(2015)^{7}$ studied the customer perception towards online insurance. For the study primary data was collected through questionnaire and field work and secondary data was collected from government records, newspapers, business magazines, websites and other sources. Chi-square a technique was used for analyzing the data and study suggested adopting specific measures to enhance the online initiatives to drive the growth further.

Bihani \& Bhowal $(2016)^{8}$ studied image gap between the expectation and experience of the customers in Johrat.
The primary data was collected through questionnaire for the study from the Jorhat district. The result revealed that the difference between the degree of customer Solution expected from the insurance and the degree of customer Solution experienced is statistically significant.

\section{Statement of the Problem}

Many insurance products are been introduces in order to capture the targeted market and get more profit. The services companies which were meant to give service are now focusing on profit. What they want from the insurance company in terms of product and services, whether agents are being trained to understand the needs of a client. Are they offering and suggesting them the policy which actually meets the client needs or just selling the policy. Additional benefits can be bought in the form of riders as cover against deadly disease, surgeries and disability due to accident.

This research is trying to investigate, identifying and analyzing the factors which influence the customer perception towards general insurance of Gwalior region, how the clients make decision. What are the factors being consider before purchasing any general insurance policy. This research will help private and public insurance company to identify the customer perception and will help in introducing correct product and services in market.

\section{Objectives of the study}

The following are the specific objectives of the study:

1. To design and develop a model which influences the perception of the insurance policy holders.

2. To differentiate the customer a perception towards general insurance on the gender basis.

3. To differentiate the customer perception towards general insurance on the occupation basis.

4. To differentiate the customer perception towards general insurance on the sector basis.

5. To identify the factors influencing Customer perception towards General Insurance.

\section{Research Methodology}

This study is an analytical and descriptive research. It is related to the analysis of customer perceptiontowards general insurances. In order to conduct this study, customers of various general insurance companies are the respondents of this study. To meet the objective of the study the self designed questionnaire for the measure were developed to identify the factors that affect the mindset of individuals. This questionnaire included 18 closed-ended questions regarding the factors on a 5 point likert scale. The primary data is collected from 200 insurance policy holders from Gwalior. 


\section{Tools used for data analysis}

1. The croanbach alpha reliability method was applied on data collected. To check the reliability of used measures in the current study so that if the similar study would be conducted in the near future, so the results of that study would be reliable or repeatable.

2. Exploratory factor analysis was applied to customer perception to identify underlying factors of measured used in the current study.

3. ANOVA is used to test the variances among the group.

\section{Hypothesis}

1. Null Hypothesis(Ho): There is no significant difference in customer perception across gender.

2. Null Hypothesis(Ho): There is no significant difference in customer perceptionacross occupation.

3. Null Hypothesis(Ho): There is no significant difference in customer perception across sector.

\section{Result and Interpretations}

\section{Reliability analysis}

A reliability test was carried out by using IBM SPSS 21 software. Where in Cronbach's alpha reliability test is was applied to check the reliability coefficient, which was computed for the entire statement used in the questionnaire.

\begin{tabular}{|c|c|c|}
\hline \multicolumn{2}{|l|}{ Reliability Statistics } & \multicolumn{2}{|c|}{$\begin{array}{c}\text { Cronbach's Alpha } \\
\text { Cronbach's Alpha }\end{array}$} & $\begin{array}{c}\text { No. of } \\
\text { Items } \\
\text { Items }\end{array}$ & 18 \\
\hline .828 & .830 & 18 \\
\hline
\end{tabular}

The reliability test revealed the results wherein Cronbach's alpha reliability which was found to be 0.830 . The value of Croanbach's Alpha reliability which is more than the standardize value (0.7). Hence, it can be said that all the statement of the questionnaire are valid and the questionnaire can be treated has highly reliable.

\section{ANOVA}

Levene's test for homogeneity of variances assesses whether the population variances for the groups are significantly different from each other.

\begin{tabular}{|c|c|c|c|}
\hline \multicolumn{4}{|c|}{ Levene's test of equality of error variances } \\
\hline \multicolumn{4}{|c|}{ Dependent Variable: Customer perception } \\
\hline $\mathrm{F}$ & df1 & $\mathrm{df} 2$ & Sig. \\
\hline 1.319 & 7 & 188 & .243 \\
\hline \multicolumn{4}{|c|}{$\begin{array}{l}\text { Tests the null hypothesis that the error variance of the } \\
\text { dependent variable is equal across groups. }\end{array}$} \\
\hline \multicolumn{4}{|c|}{$\begin{array}{l}\text { a. Design: Intercept }+ \text { gender }+ \text { occupation }+ \text { sector }+ \\
\text { gender } * \text { occupation }+ \text { gender } * \text { sector }+ \text { occupation } * \\
\text { sector }+ \text { gender } * \text { occupation } * \text { sector }\end{array}$} \\
\hline
\end{tabular}

The null hypothesis states that the Levene's statistics test has a value of 1.319 and the p- value of.243 predicts that we do not reject the null hypothesis and we conclude that the data do not violate homogeneity of variance assumption and that is why we will proceed with interpretation of ANOVA.

\section{Tests of between-subjects effects}

Dependent Variable: perception

\begin{tabular}{|l|c|c|c|c|c|}
\hline Source & Type III Sum of Squares & Df & Mean Square & F & Sig. \\
\hline Corrected Model & $1123.916^{\mathrm{a}}$ & 7 & 160.559 & 2.625 & .013 \\
\hline Intercept & 98267.113 & 1 & 98267.113 & 1606.505 & .000 \\
\hline Gender & 11.252 & 1 & 11.252 & .184 & .668 \\
\hline Occupation & 3.383 & 1 & 3.383 & .055 & .814 \\
\hline Sector & 152.012 & 1 & 152.012 & 2.485 & .117 \\
\hline gender * occupation & 19.440 & 1 & 19.440 & .318 & .574 \\
\hline gender * sector & 254.579 & 1 & 254.579 & 4.162 & .043 \\
\hline occupation * sector & 196.976 & 1 & 196.976 & 3.220 & .074 \\
\hline gender * occupation * sector & 213.945 & 1 & 213.945 & 3.498 & .063 \\
\hline Error & 11499.635 & 188 & 61.168 & & \\
\hline Total & 1075290.000 & 196 & & & \\
\hline Corrected Total & 12623.551 & 195 & & & \\
\hline
\end{tabular}

a. $\mathrm{R}$ Squared $=.089$ (Adjusted R Squared $=.055$ ) 
In case of hypothesis 1 , null hypothesis is not rejected because F-value is 0.184 at p-value 0.668 which concludes that there is no significant difference in customer perception across gender. In case of hypothesis 2 , null hypothesis is not rejected because $\mathrm{F}$-value is.055at p-value 0.814 which concludes that there is no significant difference in customer perception across occupation.

In case of hypothesis 3, null hypothesis is not rejected because F-value is 2.485 at p-value 0.117 which concludes that there is no significant difference in customer perception across sector.

The combined effect of gender and occupation were also not significant in case of customer perception as F-value.318 is at p-value.574. The combined effect of sector and occupation is significant at $10 \%$ level of significance as Fvalue is 3.220 at p-value.074. The combined effect of gender and sector were significant in case of customer perception as F-value 4.162 is at p-value.043.

\section{Factor Analysis}

Factor analysis using the Principal Component method with Varimax rotation. However, before applying factor analysis, the data was tested for its appropriateness. KMO \&
Bartlett's Test were applied to test the appropriateness of the data. Wherein, the result of The Kaiser - Meyer - Olkin Measure of Sampling Adequacy was found to be 0.767, indicating that the sample was adequate enough to consider the data as normally distributed in the current study.

\begin{tabular}{|l|r|}
\hline \multicolumn{2}{|l|}{ KMO and Bartlett's Test } \\
\hline \multicolumn{2}{|l|}{ Kaiser-Meyer-Olkin Measure of Sampling } \\
Adequacy.
\end{tabular}

The Bartlett's Test of sphericity led a null hypothesis that the item to item correlation matrix is identical matrix. The result of Bartlett's test of Sphericity was evaluated through the Chi-Square Value, the value of Chi-square was found to be 933.034 which is significant at $0.000 \%$ level of significance. Therefore, the null hypothesis stating 'item to item correlation as identity matrix' is rejected, indicating that the data is suitable and normally distributed so it can be used for factor analysis.

\begin{tabular}{|c|c|c|c|c|}
\hline \multirow[t]{2}{*}{ Factor name } & \multicolumn{2}{|c|}{ Eigen Value } & \multirow[t]{2}{*}{ Variable convergence } & \multirow{2}{*}{$\begin{array}{c}\text { Loading } \\
\text { value }\end{array}$} \\
\hline & Total & $\begin{array}{c}\text { \% of variance } \\
\text { explained }\end{array}$ & & \\
\hline \multirow[t]{5}{*}{ Loyalty } & \multirow[t]{5}{*}{2.311} & \multirow[t]{5}{*}{12.841} & $\begin{array}{l}\text { Q 7. Your General Insurance Company performs the service } \\
\text { in first instance. }\end{array}$ & .422 \\
\hline & & & $\begin{array}{l}\text { Q } 12 \text { Your General Insurance Companies settle customers' } \\
\text { claims without any delay. }\end{array}$ & .625 \\
\hline & & & $\begin{array}{l}\text { Q } 13 \text { Guidance or help provided by at the time of taking } \\
\text { policy of your General Insurance Company. }\end{array}$ & .781 \\
\hline & & & $\begin{array}{l}\text { Q } 14 \text { Claim settlement amount by your General Insurance } \\
\text { Company. }\end{array}$ & .599 \\
\hline & & & Q 15 Goodwill of your General Insurance Company. & .512 \\
\hline \multirow[t]{4}{*}{ Transparency } & \multirow[t]{4}{*}{2.031} & \multirow[t]{4}{*}{11.286} & $\begin{array}{l}\text { Q } 8 \text { Your General Insurance Company provides the services } \\
\text { as promised. }\end{array}$ & .853 \\
\hline & & & $\begin{array}{l}\text { Q } 10 \text { Your General Insurance Company offer diversified } \\
\text { products and policies. }\end{array}$ & .497 \\
\hline & & & $\begin{array}{l}\text { Q } 11 \text { Terms of Insurance policies issued by your general } \\
\text { insurance company is clear and transparent }\end{array}$ & .498 \\
\hline & & & $\begin{array}{l}\text { Q 17. Your General insurance company reminds you to } \\
\text { renew the policy. }\end{array}$ & .583 \\
\hline \multirow[t]{3}{*}{ Proficiency } & \multirow[t]{3}{*}{1.956} & \multirow[t]{3}{*}{10.868} & Q 4 Knowledge of the person dealing with you. & .760 \\
\hline & & & $\begin{array}{l}\text { Q } 6 \text { When customers have a problem your General Insurance } \\
\text { Company shows sincere interest in solving it. }\end{array}$ & .650 \\
\hline & & & $\begin{array}{l}\text { Q } 5 \text { Materials associated with the Services (Such as } \\
\text { pamphlets or Brochure) are visually appealing of your }\end{array}$ & .517 \\
\hline
\end{tabular}




\begin{tabular}{|c|c|c|c|c|}
\hline & & & General Insurance Company. & \\
\hline \multirow[t]{3}{*}{ Reliable } & \multirow[t]{3}{*}{2.263} & \multirow[t]{3}{*}{12.572} & $\begin{array}{l}\text { Q } 3 \text { Employees and agents attitude of your General Insurance } \\
\text { Company in guiding claim settlement. }\end{array}$ & .470 \\
\hline & & & $\begin{array}{l}\text { Q } 16 \text { Your General Insurance Company has competitive price } \\
\text { of their products and services. }\end{array}$ & .791 \\
\hline & & & $\begin{array}{l}\text { Q 18Moral support by the employees and agents of General } \\
\text { Insurance Company. }\end{array}$ & .782 \\
\hline \multirow[t]{3}{*}{$\begin{array}{l}\text { Convenient } \\
\text { Services }\end{array}$} & \multirow[t]{3}{*}{1.768} & \multirow[t]{3}{*}{9.823} & $\begin{array}{l}\text { Q } 1 \text { Your General Insurance Companies has modern } \\
\text { equipment and technology. }\end{array}$ & .813 \\
\hline & & & $\begin{array}{l}\text { Q } 2 \text { The physical facilities of your General Insurance } \\
\text { Companies are visually appealing. }\end{array}$ & .667 \\
\hline & & & $\begin{array}{l}\text { Q } 9 \text { Your General Insurance Company insists on error free } \\
\text { records(i.e. issuing error-free bills, statements, receipts, } \\
\text { contracts, etc. }\end{array}$ & .507 \\
\hline
\end{tabular}

\section{Description of factor}

\section{Loyalty (2.311)}

This factor is important factor which explained $12.841 \%$ of variation the factors as Q7(.422), Q12(.625), Q13(.781), Q14(.599) and Q15(.512) are correlated with each other. All these statements reflect loyalty of services of general insurance companies.

\section{Reliable (2.263)}

The second factor explained the $12.572 \%$ variance. The extracted factors are Q3(.470) Q16(.791) and Q18(.782). The statements indicate the claim settlement of the policy so termed as reliable or trustworthy.

\section{Transparency (2.031)}

The third factor explained $11.286 \%$ of variances. In this segment the important variables are Q8 (.853), Q10(.497), Q11(.498) and Q17(.583).The statement indicates the terms and condition of the policy so termed as Transparency.

\section{Proficiency (1.956)}

The fourth factor explained $10.868 \%$ of variances. In this segment the important variables are Q4(.760), Q6(.650), Q11(.517), Q17(.583). The statement includes state about the ability of the employees, agents and staff. So the factor is termed as the proficiency.

\section{Convenient services (1.768)}

The fifth factor explained the $9.823 \%$ of the variance. The variable of this factor are Q1 (.813), Q2(.667) and Q9(.507). The statement indicates the technology so it is termed as convenient services.

\section{Implications of the Study}

1. This research can be used by the insurance companies to understand the perception of the customers towards general insurance.

2. The research can be use by the insurance sector to decide the policy.

3. References of study can also be helpful for further research.

\section{Suggestion of the Study}

1. The analysis is based on 200 respondents and if we increase the no. of respondent result may vary.

2. To ensure generalization further study should be carried out a much large sample.

3. The current study was carried out for using purposive technique. This shows limitation is terms of sampling error.

4. This research has been done in Gwalior region, further study can be done in any other region.

\section{Conclusion}

The competitive climate in the Indian insurance market has changed dramatically over the last one decade. With the rise in risk and rapidly increasing in the expenses now a day's people prefer to take insurance to financial secured themselves from the uncertainties. After applying the test it can we conclude that Loyalty, Transparency, Reliable, Proficiency and convenient services are the factors which affect the Customer perception towards General Insurance. There is no difference in the perception of the customer towards general insurance across gender, sector and occupation. The insurance companies should consider the above factors before taking decision. 


\section{Source of Funding}

None.

\section{Conflict of Interest}

None.

\section{References}

1. Sharma A. Managerial competencies for middle-level managers of general insurance sector In India. Siddhant-A $J$ Decis Mak. 2011;11(1):27-39.

2. Taha TAEA, Ibrahim Y, Minai MS. Forecasting general insurance loss reserves in Egypt. Afr J Business Manag, 2011;5(22):8961-70.

3. Sandhu HS, Bala N. Customers' perception towards service quality of Life Insurance Corporation of India: A factor analytic approach. Int J Business Soc Sci. 2011;2(18):219-31.

4. Kavitha T. Latha A, Jamuna S. Customers attitude towards general insurance-a factor analysis approach. $J$ Business Manag. 2012;2(1):30-6.
5. Turquet $P$. Health insurance system financing reforms in the Netherlands, Germany and France: Repercussions for coverage and redistribution?. Int Soc Secur Rev. 2012;65(1):29-51.

6. Jain D, Lodha A. Determinants of satisfaction for general insurance products- An empirical study in Rajasthan. In proceedings of the National Conference on Emerging Challenges for Sustainable Business, IIT Roorkee.

7. Thangadurai P, Rahim A. Policyholders perception towards online insurance a pilot study in Mumbai. Int J Appl Res. 2015;1(11):522-6.

8. Bihani P, Bhowal A. Customer solution-important factor for image gap analysis of life insurance services in Jorhat; 2012.

How to cite: Gangil R, Vishnoi S. Customer perception towards general insurance: A factor analysis approach. J Manag Res Anal. 2020;7(1):15-20. 